\title{
Environmental risk of trace elements in P-containing fertilizers marketed in Brazil
}

\author{
Fernando Bruno Vieira da Silva ${ }^{1 *}$, Clístenes Williams Araújo do Nascimento ${ }^{1}$, Paula Renata \\ Muniz Araújo ${ }^{1}$
}

${ }^{1}$ Departament of Agronomy, Federal Rural University of Pernambuco, Dom Manuel de Medeiros street, s/ $n$ Dois Irmãos - 52171-900 - Recife, PE - Brazil.*Corresponding author: fernando.vsilva@ufrpe.br.

\begin{abstract}
The input of trace elements (TEs) into agricultural soils from phosphate fertilizers may compromise the sustainability of agroecosystems and pose a risk to human health. We evaluated 53 sources of P marketed in Brazil in regard to $\mathrm{As}, \mathrm{Cd}, \mathrm{Cr}, \mathrm{Hg}$, and $\mathrm{Pb}$ concentrations in order to assess the risks associated with their application to soils. Based on the concentrations of TEs and the consumption of different sources, we estimated the amounts of TEs added annually to agricultural soils. $\mathrm{As}, \mathrm{Cr}, \mathrm{Pb}$, and $\mathrm{Hg}$ concentrations did not exceed those found in fertilizers sold in other regions of the world. Phosphate rocks had Cd concentrations that were twice as high as any other source. The potential risk of Cd affecting soil quality is at least nine times higher than that of the other TEs assessed. Due to high consumption, monoammonium phosphates and single superphosphates are the main sources of TEs to Brazilian soils. In general, TEs in P-containing fertilizers sold in Brazil did not pose a high human health risk in a medium time frame. Nevertheless, intensive application of fertilizers with high concentrations of TEs requires monitoring of the TE accumulation in soils to ensure the sustainability of agroecosystems.
\end{abstract}

Keywords: Rock phosphate, agricultural soils, heavy metals, cadmium, arsenic

\section{Introduction}

Currently, Brazil has 69.2 million hectares of cultivated land and is one of the leading food producers in the world (IBGE, 2012; MAPA, 2016). As a result of such intensive agriculture, Brazil is the world's fourth largest fertilizer consumer after China, India, and the USA (IFA, 2016). In 2015, the estimated consumption of fertilizers was nearly 30 million tonnes, of which $38 \%$ is related to phosphate fertilizers alone (IPNI, 2016).
Although fertilizer use is essential for meeting the crop demand for nutrients exported from soil, fertilizers can contain trace elements (TEs) that are inadvertently added to the soil (Kratz et al., 2016). The amount of TEs transferred to the soil in a single application of fertilizer is very low or negligible. However, repeated applications of fertilizers with relatively high contents of TEs can lead to significant accumulation (Jiao et al., 2012). 
Therefore, elements such as $\mathrm{As}, \mathrm{Cd}, \mathrm{Cr}, \mathrm{Hg}$, and $\mathrm{Pb}$ can affect soil quality and pose a risk to human and animal health through food chain contamination (Hosseinpur and Motaghian, 2015).

Trace elements are present in fertilizers as a result of the composition of raw materials used in their manufacture. Phosphate rocks and industrial/ animal wastes are among the main sources of TEs in agricultural soils (Gonçalves Jr et al., 2014; Seshadri et al., 2015). The concentration of TEs in nitrogen and potassium fertilizers is usually very low, and hence, their application does not imply a significant accumulation of TEs (McBride and Spiers, 2001). On the other hand, the prolonged use of P-containing fertilizers is a major source of TEs in soils, particularly Cd (Jiao et al., 2012). For instance, soils cultivated with sugarcane and fertilized for a long period with phosphate fertilizers accumulated $\mathrm{Cd}$ levels above the allowable limit according to Brazilian legislation (Silva et al., 2016). Estimates of the annual input of TEs in soil via phosphate fertilizers range from 22.0 to $299.0 ; 24.0$ to $30.0 ; 319.0$ to $1626.0 ; 0.1$ to 17.0 ; and 10.0 to 777.0 tonnes for $\mathrm{As}, \mathrm{Cd}, \mathrm{Cr}, \mathrm{Hg}$, and $\mathrm{Pb}$, respectively (Luo et al., 2009; ).

Due to the risk associated with the presence of TEs in fertilizers, several countries have limited the concentrations of these elements in marketable products (Gonçalves Jr et al., 2014; Jiao et al., 2012; Kratz et al., 2016). In Brazil, Normative Instruction No. 27/2006 of the Ministry of Agriculture, Livestock and Supply (MAPA) established maximum allowable concentrations of TEs in fertilizers (MAPA, 2006). However, few studies have evaluated the concentration and risk of As,
$\mathrm{Cd}, \mathrm{Cr}, \mathrm{Hg}$, and $\mathrm{Pb}$ in P-containing fertilizers used in Brazil. Cadmium is the most studied element, especially in phosphate rocks (Freitas et al., 2009). There is also a scarcity of data on the supply of TEs via fertilizers in Brazilian soils since a plethora of mineral and organic sources are used.

Human and animal health risks associated with TEs in fertilizers need to be evaluated carefully (Hartley et al., 2013). As the concentrations of TEs vary markedly with the raw materials available in each region or country, the production of local and regional data is essential. In this scenario, we aimed to assess the concentrations of $\mathrm{As}, \mathrm{Cd}, \mathrm{Cr}, \mathrm{Hg}$, and $\mathrm{Pb}$ in $\mathrm{P}$-containing fertilizers marketed in Brazil in order to estimate the accumulation of TEs in agricultural soils through phosphorus fertilizer use. In addition, we estimated both the total amount ( $\mathrm{kg}$ year $\left.{ }^{-1}\right)$ and the rate $\left(\mathrm{g} \mathrm{ha}^{-1}\right.$ year $\left.{ }^{-1}\right)$ of TEs applied to soils with aims to calculate the number of mineral fertilizer applications needed to reach the limit of TEs in agricultural soils established by Brazilian legislation (MAPA, 2006).

\section{Materials and Methods}

\subsection{Selection, preparation, and analysis of trace elements in fertilizers}

We analyzed 53 P-containing fertilizers sold in Brazil and obtained from the National Agricultural Laboratory (LANAGRO-PE) of MAPA (Table 1). The samples were dried at $60{ }^{\circ} \mathrm{C}$, pulverized in an agate mortar, and passed through a $0.30-\mathrm{mm}$ mesh stainless steel sieve. 
Table 1. Description of the phosphate fertilizers evaluated in this study

\begin{tabular}{lccc}
\hline Product & $\begin{array}{c}\text { Number } \\
\text { of } \\
\text { samples }\end{array}$ & $\begin{array}{c}(\%) \\
\mathrm{P}_{2} \mathrm{O}_{5}{ }^{\mathrm{a}}\end{array}$ & $\begin{array}{c}\text { Consumption } \\
(1,000 \mathrm{t})^{\mathrm{b}}\end{array}$ \\
\hline $\begin{array}{l}\text { Rock phosphate (RP) } \\
\text { Monoammonium phosphate }\end{array}$ & 5 & 24 & 184.09 \\
$\begin{array}{l}\text { (MAP) } \\
\text { Simple superphosphate (SSP) }\end{array}$ & 23 & 50 & 3558.41 \\
$\begin{array}{l}\text { Multi-nutrient fertilizers (NPK) } \\
\text { Organo-mineral + rock phosphate }\end{array}$ & 12 & 13 & 5336.79 \\
$($ OM+RP) & 6 & 26 & 1519.27 \\
\hline
\end{tabular}

(a) average value of samples certified by manufacturers; (b) Brazilian consumption in 2015 (ANDA, 2015); $n d$ not available.

1.000 gram of the various fertilizer powder samples was digested by adding $9 \mathrm{~mL} \mathrm{HNO} 3+3 \mathrm{~mL} \mathrm{HCl}$ in a microwave oven at $175{ }^{\circ} \mathrm{C}$ for 4 minutes and $30 \mathrm{sec}-$ onds (USEPA, 1998). This method provides similar results to the official method currently in use in Brazil (MAPA, 2006), and it is preferred due to the lower cost of acids, shorter digestion time, and higher reproducibility (Silva et al., 2014). All analyses were performed in duplicate.

For quality control, we also analyzed blank samples and a multi-element fertilizer (SRM 695) with certified TE concentrations (National Institute of Standards and Technology, USA). The recoveries of TEs obtained from the certified sample were 97, 100, 72, 90 , and $73 \%$ for $\mathrm{As}, \mathrm{Cd}, \mathrm{Cr}, \mathrm{Hg}$, and $\mathrm{Pb}$, respectively. $\mathrm{Cd}, \mathrm{Cr}$, and $\mathrm{Pb}$ concentrations were determined by optical emission spectrometry (ICP-OES) (Perkin-Elmer/ICP-OES 8000), while As and Hg concentrations were measured by hydride generation atomic absorption spectroscopy (HGAAS) (Perkin-Elmer/AA 800).

\subsection{Inputs of trace elements to soils via fertilizers}

Equation 1 was used to estimate the total annual inputs (tonne year ${ }^{-1}$ ) of TEs in soil via P-containing fertilizers. Other inputs and losses of TEs in agricultural soils such as atmospheric deposition, crop uptake or leaching were not included in this calculation.

$$
T A_{i}=\sum_{j}\left(Q_{j} \times C_{i j}\right) \times 10^{-6}
$$

Where TAi is the total amount of the TE (i) added each year (tonne year ${ }^{-1}$ ) from P-containing fertilizers (j), Qj is the amount of fertilizer (tonne) currently consumed in Brazil, and Cij is the TE concentration in the fertilizer $\left(\mathrm{mg} \mathrm{kg}^{-1}\right)$. The rate of application $\left(\mathrm{g} \mathrm{ha}^{-1}\right.$ year $^{-1}$ ) was estimated with equation 2 :

$$
T A_{i j}=\left[\left(\frac{\bar{D}}{F P_{j}}\right) \times C_{i j}\right] \times 10^{-3}
$$

Where TAij is the amount of TE (i) added annually per unit area through fertilizer (j) $\left(\mathrm{g} \mathrm{ha}^{-1}\right), \mathrm{D}$ is the average recommended dose for the main crops grown in Brazil (140 kg ha-1 $\mathrm{P}_{2} \mathrm{O}_{5}$ ) (CFSEMG, 1999; IPA, 2008), and $\mathrm{FP}_{\mathrm{j}}$ is the fraction of $\mathrm{P}_{2} \mathrm{O}_{5}$ in fertilizers $(0.18,0.24,0.26$ and 0.50 for SSP, RP, OM+RP and MAP, respectively) (dimensionless). 
We also estimated the number of applications needed to increase the TE natural background of the soil surface layer (0-0.2 $\mathrm{m}$ ) up to the permissible limit for agricultural soils established by Brazilian legislation (CONAMA, 2009). The estimate was applied only to fertilizers with high addition of TEs:

$$
N A_{j}=\frac{2.6 \times 10^{3} \times A L_{i}}{T A_{i j}}
$$

Where $N A_{j}$ is the number of fertilizer (j) applications required to increase the TE concentration (i) in the topsoil up to the allowable limit (AL) $\left(\mathrm{mg} \mathrm{kg}^{-1}\right)$, and $2.6 \times 10^{3}$ is the unity conversion factor $\mathrm{g} \mathrm{ha}^{-1}$ to $\mathrm{mg} \mathrm{kg}{ }^{-1}$ of the parameter $\mathrm{TA}_{\mathrm{ij}}$, taking into account the depth of $0.2 \mathrm{~m}$ and the soil density of $1300 \mathrm{~kg} \mathrm{~m}^{-3}$ (Ferreira, 2010) for the calculation of the soil mass in 1 hectare.

\subsection{Statistical analyses}

Descriptive statistics of the dataset were obtained by calculating the mean, median, standard deviation and amplitude. The data with a normal distribution assumption were verified by the Shapiro-Wilk test $(p>0.05)$. Data without a normal distribution were normalized through logarithmic transformation.
Hierarchical cluster analysis (AH) was applied to group different types of P-containing fertilizers. $\mathrm{AH}$ was carried out using Ward's algorithm with the Euclidean distance as a binding measure and the dissimilarity between the products was assessed as a function of the TE concentration. Statistical analyses were performed using STATISTICA software (version 10.0).

\section{Results}

\subsection{Trace element concentrations in P-fertilizers}

The mean concentration of TEs in fertilizers had the following descending order: $\mathrm{Cr}(67.9)>\mathrm{Pb}(19.2)>$ $\mathrm{Cd}(9.4)>\mathrm{As}$ (6.6) >> Hg (0.1). The highest values found for $\mathrm{As}, \mathrm{Cd}, \mathrm{Hg}$, and $\mathrm{Cr}$ were approximately 7 times higher than their respective median values, and the $\mathrm{Pb}$ concentration was 17 times higher than the median $\mathrm{Pb}$ value (Table 2). The distributions of As and $\mathrm{Pb}$ concentrations in the fertilizers had a similar trend, with over $65 \%$ of the data lying in the ranges of 0.5 to 4.2 and 0.3 to $14.7 \mathrm{mg} \mathrm{kg}^{-1}$, respectively. More than $80 \%$ of the $\mathrm{Cd}$ and $\mathrm{Cr}$ concentrations were $<17.2 \mathrm{mg}$ $\mathrm{kg}^{-1}$ and $<148.1 \mathrm{mg} \mathrm{kg}^{-1}$, respectively. On the other hand, Hg showed low variability with a high percentage of samples near the mean concentration.

Table 2. Descriptive statistics of the trace elements content in fertilizers containing P sold in Brazil

\begin{tabular}{|c|c|c|c|c|c|c|}
\hline \multirow{2}{*}{$\begin{array}{l}\text { Trace } \\
\text { elements }\end{array}$} & Minimum & Maximum & Mean & Median & $\pm \mathrm{SD}$ & \multirow{2}{*}{ SW- $p$} \\
\hline & \multicolumn{5}{|c|}{ - $\left(\mathrm{mg} \mathrm{kg}^{-1}\right)$ - } & \\
\hline As & 0.54 & 26.72 & 6.55 & 3.41 & 7.23 & $<0.001$ \\
\hline $\mathrm{Cd}$ & 0.40 & 40.03 & 9.39 & 6.05 & 10.08 & $<0.001$ \\
\hline $\mathrm{Cr}$ & 10.72 & 341.75 & 67.82 & 51.67 & 77.31 & $<0.001$ \\
\hline $\mathrm{Hg}$ & 0.06 & 0.54 & 0.14 & 0.11 & 0.09 & $<0.001$ \\
\hline $\mathrm{Pb}$ & 0.35 & 102.46 & 19.18 & 6.03 & 27.64 & $<0.001$ \\
\hline
\end{tabular}

$S D$ standard deviation; $S W-p p$-value of the Shapiro-Wilk normality test. 
Three groups of fertilizers regarding TE concentration were distinguished by hierarchical cluster analysis (Figure 1). In the group of high concentrations, the organic-mineral fertilizers were the main representatives, with $83 \%$ of the evaluated organic-mineral fertilizers presenting high concentrations of trace elements. Mixed fertilizers have phosphorus sources with the highest number of cases (58\%) in the group with low concentrations of trace elements. This is due to the fact that sources of $\mathrm{N}$ and $\mathrm{K}$ present very low concentration of metals (Luo et al., 2009), which causes a dilution effect.

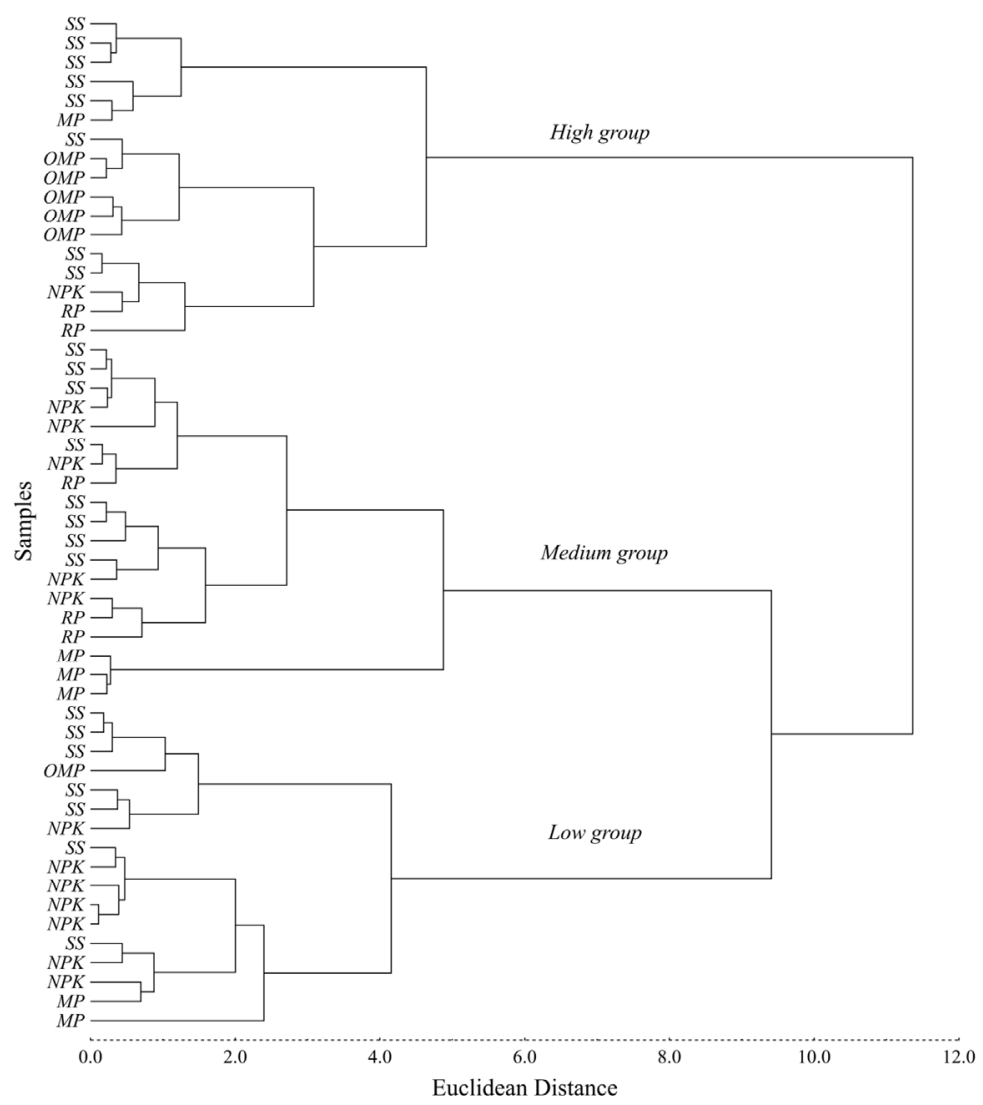

Figure 1. Hierarchical clustering of phosphate fertilizers as the contents metals using as criterion the concentrations of $\mathrm{As}, \mathrm{Cd}, \mathrm{Cr}, \mathrm{Hg}$ and $\mathrm{Pb}$ in products. $S S$ simple superphosphate, $N P K$ multi-nutrient fertilizers, $R P$ rock phosphate, $O M P$ organo-mineral + rock phosphate and $M P$ monoammonium phosphate.

The mean concentrations of $\mathrm{As}, \mathrm{Hg}$, and $\mathrm{Pb}$ were higher in organic-mineral fertilizers, while monoammonium phosphate (MAP) and phosphate rock (PR) presented the highest concentrations of $\mathrm{Cr}$ and $\mathrm{Cd}$, respectively (Figure 2). The mean concentration of $\mathrm{Pb}$ in organic-mineral + phosphate rock $(\mathrm{OM}+\mathrm{PR})$ was 8 times higher than other sources (Figure 2e). 

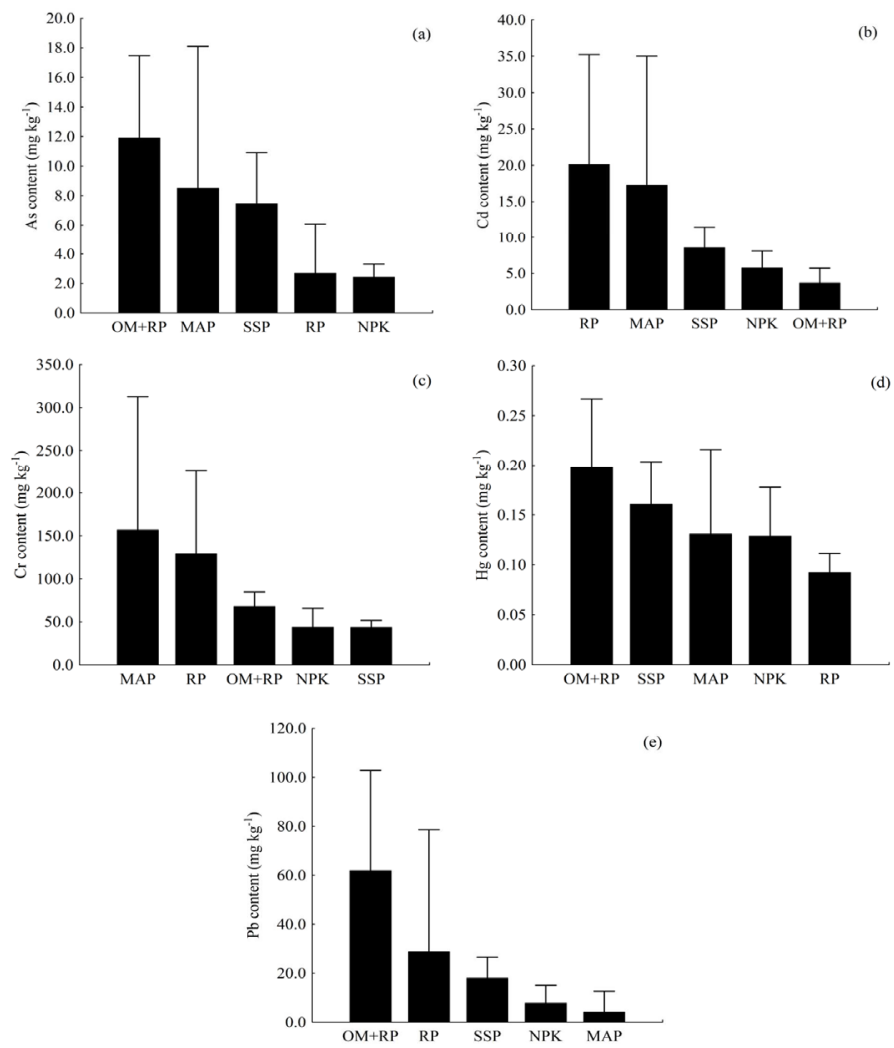

Figure 2. Average contents (standard deviation) of $\mathrm{As}(\mathrm{a}), \mathrm{Cd}(\mathrm{b}), \mathrm{Cr}(\mathrm{c}), \mathrm{Hg}(\mathrm{d})$ and $\mathrm{Pb}(\mathrm{e})$ in different types of $\mathrm{P}$ containing fertilizers marketed in Brazil. RP phosphate rock, SSP simple superphosphate, MAP monoammonium phosphate and $O M P+R P$ organo-mineral + rock phosphate.

Phosphate rocks presented mean Cd concentrations two times higher than those of other fertilizers except for MAP (Figure 2b). A similar concentration of Cd was found in phosphate rocks of sedimentary origin marketed in Germany (Kratz et al., 2016), while the Cd content observed in this study was 4 times higher than in phosphate rocks of igneous origin (Campos et al., 2005).

\subsection{Addition of trace elements in soil via fertilizers}

The average addition rates $\left(\mathrm{g} \mathrm{ha}^{-1}\right.$ year $\left.^{-1}\right)$ for the TEs were 4.0 (As), 6.3 (Cd), 47.3 (Cr), 0.08 (Hg), and $16.3(\mathrm{~Pb})$. The average addition rates for all elements in our study exceed the average additions of European countries, which were 20.7, 1.0, 1.6 and $2.3 \mathrm{~g} \mathrm{ha}^{-1} \mathrm{yr}^{-1}$ for $\mathrm{Cr}, \mathrm{Pb}, \mathrm{Cd}$ and $\mathrm{As}$, respectively (Nziguheba and Smolders, 2008). 
We estimated that phosphate rock adds larger amounts of $\mathrm{Cd}$ and $\mathrm{Cr}$ than other fertilizers containing P, while the use of organic-mineral fertilizers contributes greatly to the input of $\mathrm{As}$ and $\mathrm{Pb}$ to the soil. Hg additions ranged from 0.04 (MAP) to $0.12 \mathrm{~g} \mathrm{ha}^{-1} \mathrm{yr}^{-1}$ (SSP) (Table 3). The biggest sources of TE are those with the highest levels in their composition except for $\mathrm{Cr}$ (Figure 2). Because the MAP samples are more enriched for $\mathrm{P}_{2} \mathrm{O}_{5}$ than phosphate rock, the amount of MAP needed to achieve the recommended dose is lower than that for phosphate rock.

Table 3. Mean values ( \pm standard deviation) of per unit area additions $\left(\mathrm{g} \mathrm{ha}^{-1}\right.$ year $\left.{ }^{-1}\right)$ of trace elements in agricultural soils via phosphate fertilizers marketed in Brazil

\begin{tabular}{lllll}
\hline & SSP & MAP & RP & OM+RP \\
\hline $\mathrm{Cr}$ & $33.7( \pm 3.1)$ & $43.9( \pm 17.8)$ & $75.3( \pm 20.3)$ & $36.5( \pm 3.5)$ \\
$\mathrm{Pb}$ & $14.0( \pm 3.2)$ & $1.1( \pm 1.0)$ & $16.8( \pm 10.5)$ & $33.3( \pm 8.6)$ \\
$\mathrm{Cd}$ & $6.6( \pm 1.1)$ & $4.8( \pm 2.0)$ & $11.7( \pm 3.2)$ & $2.0( \pm 0.4)$ \\
$\mathrm{As}$ & $5.8( \pm 1.3)$ & $2.4( \pm 1.1)$ & $1.6( \pm 0.7)$ & $6.4( \pm 1.2)$ \\
$\mathrm{Hg}$ & $0.12( \pm 0.02)$ & $0.04( \pm 0.01)$ & $0.05( \pm 0.01)$ & $0.11( \pm 0.01)$ \\
\hline
\end{tabular}

RP phosphate rock, SSP simple superphosphate, MAP monoammonium phosphate and OMP+RP organo-mineral + rock phosphate.

Based on the Brazilian consumption and concentrations of TEs in fertilizers, we estimated that $\mathrm{Cr}$ and $\mathrm{Pb}$ represent the largest total additions to soil, 915.8 and 209.9 t year $^{-1}$, respectively (Table 4). Minor addition was observed for $\mathrm{Hg}\left(1.72 \mathrm{t} \mathrm{year}^{-1}\right)$. The sources that incorporate more TEs in soils are SSP and MAP, which are the sources of P most consumed in Brazil (Table 1). Estimates made with fertilizer composition of TEs indicated that SSP and MAP together provide more than $90 \%$ of $\mathrm{Cd}, 86 \%$ of $\mathrm{Cr}$, and $79 \%$ of As. Organic-mineral fertilizers represented the main input of $\mathrm{Pb}$ to soils (45\%).

Table 4. Mean values ( \pm standard deviation) of total additions (tonne year ${ }^{-1}$ ) of trace elements in agricultural soils via phosphate fertilizers marketed in Brazil

\begin{tabular}{llllll}
\hline & SSP & MAP & RP & OM+RP & Total \\
\hline $\mathrm{Cr}$ & $231.3( \pm 21.4)$ & $557.7( \pm 226.7)$ & $23.8( \pm 6.4)$ & $103.0( \pm 24.5)$ & 915.8 \\
$\mathrm{~Pb}$ & $96.0( \pm 22.2)$ & $14.6( \pm 12.4)$ & $5.3( \pm 3.3)$ & $94.0( \pm 59.3)$ & 209.9 \\
$\mathrm{Cd}$ & $45.6( \pm 7.5)$ & $61.3( \pm 25.9)$ & $3.7( \pm 1.0)$ & $5.6( \pm 2.9)$ & 116.2 \\
$\mathrm{As}$ & $39.7( \pm 8.9)$ & $30.2( \pm 14.0)$ & $0.5( \pm 0.2)$ & $18.1( \pm 8.1)$ & 88.5 \\
$\mathrm{Hg}$ & $0.9( \pm 0.1)$ & $0.5( \pm 0.1)$ & $0.02( \pm 0.00)$ & $0.3( \pm 0.1)$ & 1.72 \\
\hline
\end{tabular}

$R P$ phosphate rock, $S S P$ simple superphosphate, $M A P$ monoammonium phosphate and $O M P+R P$ organo-mineral + rock phosphate. 
In order to assess whether the levels of TEs in fertilizers exceed the maximum permitted concentrations, the values of the metals are based on the percentage points of $\mathrm{P}_{2} \mathrm{O}_{5}$ established by Brazilian legislation (MAPA, 2006). This practice is also adopted in
California (USA) (AAPFCO, 2015) (Figure 3). Unlike other countries that regulate only $\mathrm{Cd}$ in phosphate fertilizers (CCR, 2007), Brazilian law regulates the concentrations $\left(\mathrm{mg} \mathrm{kg}^{-1} \% \mathrm{P}_{2} \mathrm{O}_{5}^{-1}\right)$ of $\mathrm{As}, \mathrm{Cd}, \mathrm{Cr}$, $\mathrm{Hg}$, and $\mathrm{Pb}$.
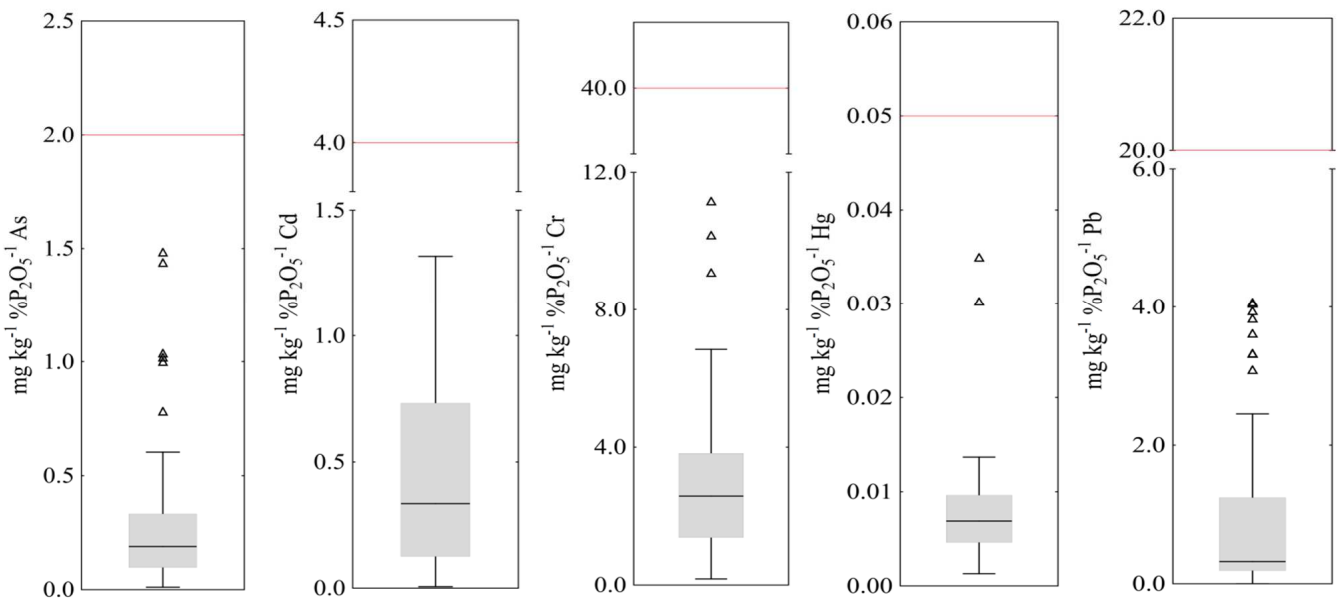

Figure 3. As, $\mathrm{Cd}, \mathrm{Cr}, \mathrm{Hg}$ and $\mathrm{Pb}$ concentrations per $\%$ of $\mathrm{P}_{2} \mathrm{O}_{5}$ in fertilizer containing $\mathrm{P}$ sold in Brazil. The dashed red line shows the permissible limits of heavy metals in phosphate fertilizers in accordance with Brazilian legislation (MAPA, 2006).

The ascending order of maximum permissible concentrations is $\mathrm{Hg}<<<\mathrm{Cd}<\mathrm{As}<<\mathrm{Pb}<\mathrm{Cr}$. Cd had the highest variability in phosphate fertilizers, with concentrations of $0.33,0.73$ and $1.31 \mathrm{mg} \mathrm{kg}^{-1} \% \mathrm{P}_{2} \mathrm{O}_{5}^{-1}$ for the median, 75th percentile and maximum values, respectively. Arsenic and $\mathrm{Pb}$ had the highest numbers of anomalous values. SSP samples showed the highest ratio of $\mathrm{As} / \mathrm{P}_{2} \mathrm{O}_{5}$, while the highest values of $\mathrm{Pb} / \mathrm{P}_{2} \mathrm{O}_{5}$ were observed for OM + PR and SSP samples.
The increases in the concentrations of TEs in soil $\left(\mathrm{mg} \mathrm{kg}^{-1}\right)$ had the following order: $\mathrm{Cr}>\mathrm{Pb}>\mathrm{Cd}>\mathrm{As}$ $>\mathrm{Hg}$. The $\mathrm{Cr}$ and $\mathrm{Pb}$ concentrations were an order of magnitude higher than those of other trace elements. The increase of $\mathrm{Hg}$ through the richest fertilizer (OM + PR) was negligible, and the estimated number of applications was $>12,000$ (Table 5). 
Table 5. Number of applications of fertilizers containing P needed to increase the concentrations of metals in the soil to the permissible limit

\begin{tabular}{cccccc}
\hline Source & $\begin{array}{c}\mathrm{P}_{2} \mathrm{O}_{5} \text { soluble } \\
(\%)\end{array}$ & $\begin{array}{c}\text { Concentration }^{(\mathrm{a})} \\
\left(\mathrm{mg} \mathrm{kg}^{-1}\right)\end{array}$ & $\begin{array}{c}\text { Increase per } \\
\text { application } \\
(\mathrm{b})\end{array}$ & $\begin{array}{c}\text { Number de } \\
\left(\mathrm{mg} \mathrm{kg}^{-1}\right)\end{array}$ & applications \\
\hline $\mathrm{As}$ & $\mathrm{OM}+\mathrm{RP}$ & 26 & 15.0 & 0.002 & 6097 \\
$\mathrm{Cd}$ & $\mathrm{RP}$ & 24 & 1.3 & 0.005 & 288 \\
$\mathrm{Cr}$ & $\mathrm{RP}$ & 24 & 75.0 & 0.029 & 2591 \\
$\mathrm{Hg}$ & $\mathrm{OM}+\mathrm{RP}$ & 26 & 0.5 & $<0.001$ & 12082 \\
$\mathrm{~Pb}$ & $\mathrm{OM}+\mathrm{RP}$ & 26 & 72.0 & 0.013 & 5621 \\
\hline
\end{tabular}

(a) Permissible limit in soil (CONAMA, 2009); (b) based on the application of $140 \mathrm{~kg} \mathrm{ha}^{-1} \mathrm{of}_{2} \mathrm{O}_{5}$ incorporated $0.2 \mathrm{~m}$ depth in soils with bulk density of $1300 \mathrm{~kg} \mathrm{~m}^{-3}, O M+R P$ organo-mineral + rock phosphate, $R P$ rock phosphate

\section{Discussion}

The As concentration found in p-containing fertilizers marketed in Brazil was the lowest among data from other parts of the world (Table 6). $\mathrm{Cr}$ and $\mathrm{Pb}$ had high mean concentrations, but the $\mathrm{Cr}$ concentration of the fertilizers marketed in the European Union is the largest in the literature, as is the $\mathrm{Pb}$ concentration in China. The average concentration of $\mathrm{Cd}$ in Brazil, Chile, and Argentina is similar to or higher than those reported for Europe and China. The concentration of $\mathrm{Cd}$ in the USA is the highest among the selected countries. Although there is a scarcity of studies on $\mathrm{Hg}$ in fertilizers, $\mathrm{Hg}$ concentrations found in phosphate fertilizers used in China amount to $0.8 \mathrm{mg} \mathrm{kg}^{-1}$, which is 6 times higher than in Brazil (Luo et al., 2009).

Table 6. Average content $\left(\mathrm{mg} \mathrm{kg}^{-1}\right)$ of $\mathrm{As}, \mathrm{Cd}, \mathrm{Cr}, \mathrm{Hg}$ and $\mathrm{Pb}$ in phosphate fertilizers marketed in Brazil and in other parts of the world

\begin{tabular}{lllllll}
\hline Site & As & $\mathrm{Cd}$ & $\mathrm{Cr}$ & $\mathrm{Hg}$ & $\mathrm{Pb}$ & Reference \\
\hline China & 13.5 & 2.6 & $n a$ & 0.9 & 30.0 & Luo et al., 2009 \\
USA (California) & 10.5 & 53.0 & $n a$ & $n a$ & $n a$ & CDFA, 1997 \\
Europe & 7.6 & 7.4 & 89.5 & $n a$ & 2.9 & Nziguheba and Smolders, 2008 \\
Argentina & $n a$ & 10.1 & 29.7 & $n a$ & 12.2 & Carnelo et al., 1997 \\
Chile & 15.1 & 12.3 & $n a$ & $n a$ & 10.4 & Molina et al., 2009 \\
Brazil & 6.6 & 9.4 & 67.8 & 0.1 & 19.2 & Present study \\
\hline
\end{tabular}

na not available; CDFA California Department of Food and Agriculture. 
Among the fertilizers we analyzed, high TE values in the $\mathrm{OM}+\mathrm{PR}$ can be explained by the use of peat as the main organic matrix for the production of organic-mineral fertilizers in Brazil (Junek et al., 2014). Peat is organic sediment formed by the decomposition of plant residues in wet and acidic conditions. Studies have shown that peat soils close to urban and industrial areas can be enriched by TEs through atmospheric deposition (Shuttleworth et al., 2014); in addition, the metal complexation capacity of organic matter makes peat an important $\mathrm{Pb}$ scavenger (Farmer et al., 2005; Hosseinpur and Motaghian, 2015). There have been no studies in Brazil that quantify the levels of TEs in the peat used for organic-mineral fertilizers; however, data from the international literature have shown that high concentrations of trace elements, especially $\mathrm{Pb}$, can be found in peat (Mighall et al., 2002).

Phosphate rocks are well known for carrying $\mathrm{Cd}$ to soils. Cadmium concentrations are generally higher in phosphate rocks of sedimentary origin than those of igneous origin (Kratz et al., 2016). The phosphate deposits in Brazil are predominantly igneous, but a significant amount of this fertilizer is imported from Morocco, Russia, China, Israel, and the US, which have mainly sedimentary reserves (IFA, 2016); the high $\mathrm{Cd}$ concentrations reported here are probably due to these imported levels.

The higher input of trace elements via fertilizers in Brazilian soils as compared to Europe is mainly due to the average rate of $\mathrm{P}$ applied to the soil. In Brazil, the average recommendation of $\mathrm{P}_{2} \mathrm{O}_{5}$ is $140 \mathrm{~kg} \mathrm{ha}^{-1}$, whereas $43 \mathrm{~kg} \mathrm{ha}^{-1}$ is the average rate in European countries. The higher demand for P in Brazilian agriculture as compared to other countries is owing to the high concentration of $\mathrm{Fe}$ and $\mathrm{Al}$ oxides in Brazilian soils that adsorb $\mathrm{P}$ through a specific adsorption mechanism (fixation) making it unavailable to plants
(Fontes and Weed 1996). We did not find data on the addition of $\mathrm{Hg}$ via fertilizers for European conditions.

When comparing the levels of metals in fertilizers with maximum concentrations allowed by Brazilian law, it was found that the P sources evaluated meet the legislative guidelines and are therefore considered safe. The potential risk for soil sustainability resulting from additions of $\mathrm{As}, \mathrm{Cr}$, and $\mathrm{Pb}$ via phosphate fertilizers are for a medium to long-term time frame. If the estimated additions of $\mathrm{Cd}$ are kept high, the concentration in the soil may exceed the allowable limit after 288 applications.

\section{Conclusions}

In general, TEs in P-containing fertilizers sold in Brazil did not pose a high human health risk in a medium timeframe. Nevertheless, intensive application of fertilizers with high concentrations of TEs requires monitoring of the TE accumulation in soils to ensure the environmental sustainability of agroecosystems. The contents of all evaluated metals were below the maximum found in other regions of the world. Organic-mineral fertilizers are an important source of $\mathrm{As}, \mathrm{Hg}$, and $\mathrm{Pb}$. Monoammonium phosphate and single superphosphates presented higher additions for $\mathrm{As}, \mathrm{Cd}$, and $\mathrm{Pb}$ in soils of Brazil. Phosphate rocks pose the main potential risk for soil quality owing to the high $\mathrm{Cd}$ concentration. Mixed fertilizers had low potential for increasing the concentration of TEs in soils.

\section{Acknowledgement}

Authors are grateful to LANAGRO (National Agricultural Laboratory at Pernambuco state, Brazil) for providing the fertilizer samples used in this study. 


\section{References}

ANDA, Associação Nacional para Difusão de Adubos. 2015. Consumo aparente de fertilizantes e matérias-primas em 2015. http://anda.org.br/ index.php?mpg=03.01. 00\&ver=por (acessed 03.06.16).

AAPFCO, Association of American Plant Food Control Officials. 2015. Statement of Uniform Interpretation and Policy (SUIP) \#25: the heavy metal rule. http:// www.aapfco.org/rules.html (accessed 09.07.16).

Campos, M.L., Nildo, F., Eduardo, A., Neto, F. 2005. Determination of cadmium, copper, chromium, nickel, lead and zinc in rock phosphates. Pesqui. Agropecu. Bras. 40, 361-367.

Carnelo, L.G.L., Miguez, S.R., Marbán, L. 1997. Heavy metals input with phosphate fertilizers used in Argentina. Sci. Total Environ. 204, $245-$ 250.

CCR, California Code of Regulations. 2007. Standards and labeling. http:// https://ccr.oal.ca.gov (acessed 21.06.16).

CDFA, California Department of Food and Agriculture. 1997. Development of risk-based concentrations for arsenic, cadmium, and lead in inorganic commercial fertilizers. https://www.cdfa.ca.gov/ (acessed 13.04.16).

CFSEMG, Comissão de fertilidade do solo do estado de Minas Gerais. 1999. Sugestões de adubação para as diferentes culturas em Minas Gerais. In: Ribeiro, A. C., Guimarães, P. T. G., Alvarez, V. H. (eds), Recomendações para o uso de corretivos e fertilizantes em Minas Gerais, First Edition. CFSEMG, Viçosa, pp: 169-257.
CONAMA, Conselho Nacional do Meio Ambiente. 2009. Resolução n 420 de 2009. http://www.mma. gov.br/port/conama/legiabre.cfm?codlegi $=620$ (acessed 19.05.16).

Farmer, J.G., Graham, M.C., Bacon, J.R., Dunn, S.M., Vinogradoff, S.I., Mackenzie, A.B. 2005. Isotopic characterization of the historical lead deposition record at Glensaugh, an organic-rich, upland catchment in rural N.E. Scotland. Sci. Total Environ. 346, 121-137.

Ferreira, M.M. 2010. Caracterização física do solo. In: van Lier, Q. J. (ed), Física do solo, First Edition. Sociedade Brasileira de Ciência do Solo, Viçosa, pp: 1-28.

Fontes, M.P.F., Weed, S.B. 1996. Phosphate adsorption by clays from Brazilian Oxisols: relationships with specific surface area and mineralogy. Geoderma. 72, 37-51.

Freitas, E.V.S., Nascimento, C.W.A., Goulart, D.F.S., Silva, J.P.S. 2009. Cadmium and lead availability to corn in soil amended with phosphorus fertilizers. R. Bras. Ci. Solo. 33, 1899-1907.

Gonçalves Jr, A.C., Nacke, H., Schwantes, D., Coelho, G.F. 2014. Heavy metal contamination in brazilian agricultural soils due to application of fertilizers. In: Hernandez-Soriano, M. C. (ed), Environment Risk Assessment of soil contamination, First Edition. Intech, Rijeka, pp: 105-134.

Hartley, T.N., Macdonald, A.J., McGrath, S.P., Zhao, F. 2013. Historical arsenic contamination of soil due long-term phosphate fertilizer applications. Environ. Pollut. 180, 259-264.

Hosseinpur, A.R., Motaghian, H. 2015. Evaluating of many chemical extractants for assessment of $\mathrm{Zn}$ and $\mathrm{Pb}$ uptake by bean in polluted soils. J. Soil Sci. Plant. Nutr. 15, 24-34. 
IBGE, Instituto Brasileiro de Geografia e Estatística. 2012. Produção Agrícola Municipal, Culturas Temporárias e Permanentes em 2012. ftp://ftp.ibge.gov.br/Producao_Agricola_ Municipal_\%5Banual\%5D/2012/pam2012.pdf (acessed 04.06.16).

IFA, International Fertilizer Association. 2016. Fertilizer consumption trends in China vs. the rest of the World. htpp://www.fertilizer.org/marketOutlooks (acessed 26.04.16).

IPA, Empresa Pernambucana de Pesquisa Agropecuária. 2008. Recomendações de adubação para o estado de Pernambuco: $2^{\text {a }}$ aproximação. IPA, Recife, 198 p.

IPNI, International Plant Nutrition Institute. 2016. Consumo aparente de fertilizantes e matérias-primas em 2015. htpp://www.brasil.ipni.net/article/ BRS-3132\#aparente (acessed 15.01.16).

Jiao, W., Chen, W., Chang, A.C., Page, A.L. 2012. Environmental risks of trace elements associated with long-term phosphate fertilizers applications : A review. Environ. Pollut. 168, 44-53.

Junek, J.O.M.O., Lara, T.S., Paiva, M.J.A., Martins, D.B., Morais, C.G. 2014. Circular técnica 06: Fertilizantes organominerais. Instituto de $\mathrm{Ci}$ ências da Saúde, Agrárias e Humanas (ISAH). http://site.uniaraxa.edu.br/wp-content/uploads/2014/09/ fertilizantes-organominerais.pdf (acessed 18.04.16).

Kratz, S., Schick, J., Schnug, E. 2016. Trace elements in rock phosphates and P containing mineral and organo-mineral fertilizers sold in Germany. Sci. Total Environ. 542, 1013-1019.

Luo, L., Ma, Y., Zhang, S., Wei, D., Zhu, Y. 2009. An inventory of trace element inputs to agricultural soils in China. J. Environ. Manage. 90, 2524-2530.
MAPA, Ministério da Agricultura, Pecuária e Abastecimento. 2006. Instrução Normativa $\mathrm{n}^{\circ} 27$ de 2006. https://www.legisweb.com.br/ legislacao/?id=76854 $($ acessed 05.08.16).

MAPA, Ministério da Agricultura, Pecuária e Abastecimento. 2016. Mercado Interno. www.agricultura.gov.br/vegetal/mercado-interno (acessed 12.01.16).

McBride, M., Spiers, G. 2001. Trace elements content of selected fertilizers and dairy manures as determined by ICP-MS. Commun. Soil Sci. Plan. 32, 139-156.

Mighall, T.M., Grattan, J.P., Timberlake, S., Lees, J.A., Forsyth, S. 2002. An atmospheric pollution history for lead-zinc mining from the Ystwyth Valley, Dyfed, mid-Wales, UK as recorded by an upland blanket peat. Geochem. Explor. Environ. Anal. 2, 175-184.

Molina, M., Aburto, F., Calderón, R., Cazanga, M., Escudey, M. 2009. Trace element composition of selected fertilizers used in Chile: phosphorus fertilizers as a source of long-term soil contamination. Soil Sediment Contam. 18, 497-511.

Nziguheba, G., Smolders, E. 2008. Inputs of trace elements in agricultural soils via phosphate fertilizers in European countries. Sci. Total Environ. 390, 53-57.

Seshadri, B., Bolan, N.S., Naidu, R. 2015. Rhizosphere-induced heavy metal(loid) transformation in relation to bioavailability and remediation. J. Soil Sci. Plant. Nutr. 15(2), 524-548.

Silva, F.B.V., Nascimento, C.W.A., Araújo, P.R.M., Silva, L.H.V., Silva, R.F. 2016. Assessing heavy metall sources in sugarcane Brazilian soils: na approach using mulltivariate analysis. Environ. Monito. Assess. http//dx.doi.org/ 10.1007/ s10661-016-5409-x. 
Silva, Y.J.A.B., Nascimento, C.W.A, Biondi, C.M., Preston, W. 2014. Comparison of digestion methods to determine heavy metals in fertilizers. R. Bras. Ci. Solo. 38, 650-655.

Shuttleworth, E.L., Evans, M.G., Hutchison, S.M., Rothwell, J.J. 2014. Assessment of lead contamination in peatlands using field portable XRF. Water Air Soil Pollut. 225, 1-13.
USEPA. 1998. Method 3051A: Microwave assisted acid digestion of sediments, sludges, soils, and oils. United States Environmental Protection Agency, Washington D C. 